\title{
EFEK HIPOGLIKEMIK INFUSA DAUN TANAMAN MAKASAR, Brucea javanica (L) Merr, PADA TIKUS HIPERGLIKEMIK YANG DIINDUKSI ALOKSAN
}

\author{
HANDA MUliasari ${ }^{1}$, CANDRA DWIPAYANA HAMDin ${ }^{1}$, MUHSINUl IHSAN ${ }^{2}$
}

${ }^{1}$ Program Studi Farmasi, Universitas Mataram, Jalan Majapahit No.62 Mataram NTB

${ }^{2} J u r u s a n$ Biologi, Fakultas Tarbiyah dan Keguruan, Universitas Islam Negeri Mataram, Jalan Gajah Mada Mataram NTB

\section{A B S T RACT}

Brucea javanica (L) Merr is a local plant used traditionally for diabetic medication in Lombok Island. The B. javanica seed has been recognized to have an antidiabetic effect, while the impact of the leave extract was understudied. The purpose of this res earch was to determine the effect of $B$. javanica leaves infusion on the blood glucose level of alloxan-induced diabetic rats. B. javanica leaves extract were applied by soaking leaves into hot water $\left(95^{\circ} \mathrm{C}\right)$ to obtain the extract concentration of $5 \%(\mathrm{w} / \mathrm{v})$. This experiment provides four treatments to rats within 15 days with five replicates for each treatment. The treatments for rats were $\mathrm{K} 1$ a positive control, K2 a negative control, K3 a healthy control, and P1 treated with leave infused water. The diabetic condition for K1, K2, and P1 was induced with an intravenous injection of $125 \mathrm{mg} / \mathrm{kgBW}$ alloxan monohydrate to the rats. After stable diabetic condition, K1 rats were treated with Glibenclamide $(0,25 \mathrm{mg} / \mathrm{kgBW})$, K2 rats were untreated, P1 rats were administered with leaves infused water of B. javanica (L) Merr 3 $\mathrm{ml} /$ day. K3 rats were uninduced and untreated. The hypoglycemic effect was observed by estimating the fasting blood glucose level of the rats every three days. After 15 days of treatments, P1 rats blood glucose level reduced by the $13,30 \%$, while K1 rats $22,04 \%$. The decrease in blood glucose level of both K1 and P1 rats have not reached the average blood glucose level of healthy rats. The result of the statistical analysis showed the infused extract effect was not significantly differed compared to positive control $(\mathrm{P}<0.05)$.

KEY WORDS: hypoglycemic effect, Brucea javanica (L) Merr, infused extract, alloxan, hyperglycemic rat

\section{PENDAHULUAN}

Diabetes mellitus (DM) merupakan penyakit kelainan metabolisme yang menjadi masalah global dan serius dengan kasus kematian 5,1 juta jiwa pertahun (Eid et al., 2014). Menurut International Diabetes Federation (IDF), sekitar 285 juta orang terkena diabetes di dunia dan diperkirakan jumlah ini meningkat menjadi 438 juta pada tahun 2030 (Chackrewarthy \& Tahbrew, 2014). Komplikasi DM menyebabkan lebih dari 1 juta orang diamputasi, setengah juta mengalami gagal ginjal, dan 1,5 juta orang mengalami kebutaan setiap tahunnya. Berdasarkan data World Health Organizaton (WHO) tahun 2000, Indonesia menempati urutan keempat kasus DM tertinggi setelah India, Cina, dan Amerika Serikat, dengan prevalensi 8,6\% dari total populasi (Nasution et al., 2014; Eid et al., 2014).

Kasus DM yang paling banyak ditemukan $(90 \%$ kasus) adalah DM tipe 2 (Chang et al., 2013; Coman et $a l ., 2012$ ) yang utamanya disebabkan oleh gangguan metabolisme glukosa. Pengobatan DM selama ini menggunakan terapi insulin dan obat-obatan sintetik seperti sulfonylurea, biguanida, dan inhibitor $\alpha$ glycosidase, namun pengobatan tersebut relatif mahal dan menimbulkan berbagai efek samping seperti gangguan pencernaan, kelainan darah (anemia hemolisis) dan hipoglikemik (Issa \& Bule, 2015; Njogu et al., 2016). Pengobatan berbasis tumbuhan menjadi alternatif yang murah, sederhana, dan aman; sehingga pencarian agen antidiabetes alami terus dikembangkan (Prameswari \& Widjanarko, 2014; Osadebel et al., 2014).
Berbagai penelitian telah melaporkan sekitar 400 tumbuhan dan senyawa yang diketahui memiliki aktivitas antidiabetes secara in vivo dan atau in vitro (Chang et al., 2013). Salah satu tumbuhan di Pulau Lombok yang diketahui memiliki aktivitas antidiabetes yang cukup tinggi berdasarkan pengalaman empiris masyarakat di daerah Sesaot (Kecamatan Narmada, Kabupaten Lombok Barat) adalah biji buah makasar (Brucea javanica (L.) Merr) (Okuyama et al., 1990). Tanaman ini dikenal juga dengan "Tanaman Wali" karena dipercaya memiliki aktivitas antidiabetes (Ablat et al., 2014), disamping aktivitas lainnya seperti antikanker (Sakaki, et al., 1986) dan antimalaria (Hout et al., 2006). Ablat et al., (2017) melaporkan fraksi etanol dan etil asetat ekstrak etanol biji buah makasar dapat menurunkan kadar gula darah mencit diabetes dan menghambat aktivitas enzim $\alpha$-glukosidase. Namun demikian, aktivitas antidiabetes infusa daun tanaman makasar belum dilaporkan. Tujuan penelitian ini adalah untuk mengetahui aktivitas antidiabetes ekstrak infusa daun tanaman makasar (Brucea javanica (L.) Merr).

\section{E T O D E}

Daun tanaman makasar diperoleh dari Desa Sesaot, Lombok Barat, NTB. Tanaman makasar telah dideterminasi di Laboratorium Biologi Universitas Mataram dengan No spesimen: 03/HM/buah makasar. Daun tanaman makasar sebanyak 5 gram direbus dengan $100 \mathrm{ml}$ air pada suhu $95^{\circ} \mathrm{C}$ selama \pm 15 menit. Air rebusan daun tanaman makasar didinginkan, kemudian ditambahkan akuades sampai volume $100 \mathrm{ml}$. Konsentrasi infusa daun tanaman makasar yaitu $5 \%$ selanjutnya digunakan untuk pengujian aktivitas antidiabetes terhadap hewan uji tikus. 
Hewan uji tikus (Rattus norvegicus) jantan galur Wistar dibeli dari Lab. Fakultas Farmasi Universitas Udayana, Bali. Sebanyak 20 ekor tikus putih galur Wistar ditimbang dan diaklimasi terlebih dahulu selama 2 minggu sebelum perlakuan. Tikus selanjutnya dibagi menjadi empat kelompok secara random, yaitu tiga kelompok kontrol dan satu kelompok perlakuan. Kelompok kontrol yaitu kontrol positif (K1) (diinduksi aloksan (125 mg/kg BB) dan diberi obat glibenclamid $0,25 \mathrm{mg} / \mathrm{kg}$ BB per hari), kontrol negatif (K2) (diinduksi aloksan dan tidak diberi obat glibenclamid), kontrol normal (K3) (tidak diinduksi aloksan dan tidak diberi obat glibenclamid); sedangkan kelompok perlakuan (P1) (diinduksi aloksan dan diberi ekstrak infusa daun tanaman makasar 5\% sebanyak $3 \mathrm{ml} /$ ekor/hari). Induksi aloksan dilakukan secara intravenal dengan dosis 125 $\mathrm{mg} / \mathrm{kgBB}$. Kadar gula darah puasa tikus diukur setiap tiga hari menggunakan alat GlucoDr ${ }^{\mathrm{TM}}$ Test Meter (model: AGM2100; Korea).
Data kadar gula darah puasa semua kelompok hewan uji dianalisis menggunakan program SPSS yaitu analisis ANOVA dilanjutkan dengan analisis LSD.

\section{HASIL DAN PEMBAHASAN}

Efek hipoglikemik infusa daun tanaman makasar diamati pada hewan uji tikus galur wistar yang diinduksi aloksan. Hasil pengamatan rata-rata kadar gula darah puasa semua kelompok perlakuan tercantum pada Gambar 1. Data kadar gula darah puasa pada hari pertama pengamatan merupakan kadar gula darah puasa tikus setelah 3 hari diinduksi dengan aloksan. Diperkirakan setelah 3 hari induksi, kadar gula darah puasa tikus hiperglikemik telah stabil. Pada hari yang sama, setelah pengamatan kadar gula darah puasa, tikus diberi perlakuan sesuai dengan kelompok perlakuan.

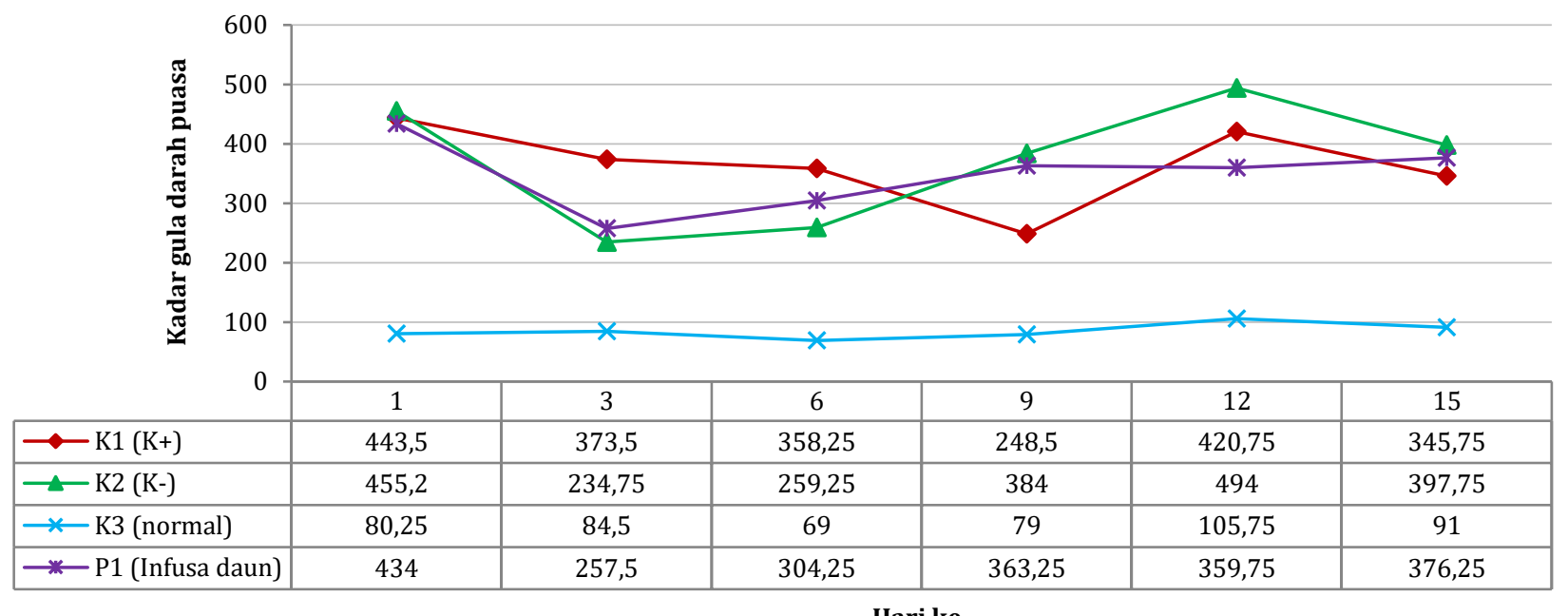

Gambar 1. Grafik rerat kadar gula darah puasa tikus pada semua kelompok perlakuan

Berdasarkan data pada Gambar 1, terjadi penurunan kadar gula darah puasa pada hari ke-3 perlakuan baik pada kontrol positif, kontrol negatif, dan infusa daun tanaman makasar. Penurunan kadar gula darah puasa pada infusa daun (40,66\%) lebih besar daripada kontrol positif (15,78\%). Penurunan kadar gula darah puasa pada kontrol negatif disebabkan oleh umpan balik negatif hormon insulin. Sel-sel $\beta$ pankreas yang belum rusak mensekresikan insulin sebagai bentuk respon homeostasis terhadap kenaikan gula darah. Pada hari ke-6 dan ke-9, terjadi kenaikan kadar gula darah puasa pada perlakuan infusa daun, sedangkan pada kontrol positif tetap mengalami penurunan. Hari ke-12 dan ke-15 pengamatan kadar gula darah puasa, infusa daun dapat mempertahankan kadar gula darah puasa hewan uji; sedangkan kontrol positif mengalami kenaikan dan penurunan kembali. Persentase penurunan kadar gula darah puasa infusa daun setelah 15 hari perlakuan adalah 13,30\%, sedangkan kontrol postifif sebesar 22,04\%. Berdasarkan analisis statistik, kadar gula darah puasa tikus pada hari ke-15 antara kelompok perlakuan dengan infusa daun dan semua perlakuan lainnya tidak berbeda nyata kecuali dengan kontrol normal (Tabel 1).
Tabel 1. Hasil analisis statistik kadar gula darah puasa tikus pada semua kelompok perlakuan pada pada hari ke-15

\begin{tabular}{ll}
\hline Perlakuan & $\begin{array}{l}\text { Rata-rata kadar gula darah } \\
\text { puasa hari ke-15 } \pm \text { SEM }\end{array}$ \\
\hline Kontrol positif & $345,75 \pm 52,36^{\mathrm{a}}$ \\
Kontrol negatif & $397,75 \pm 93,20^{\mathrm{a}}$ \\
Kontrol normal & $91 \pm 2,38^{\mathrm{b}}$ \\
Infusa daun & $287,15 \pm 49,30^{\mathrm{a}}$ \\
\hline
\end{tabular}

Keterangan: Angka yang diikuti huruf berbeda menunjukkan perbedaan yang signifikan $(P<0,05), \mathrm{SEM}=$ Standar Error Mean

Perlakuan infusa daun dan kontrol positif belum mampu menurunkan kadar gula darah puasa tikus hiperglikemik mencapai kadar normal. Hal ini kemungkinan disebabkan oleh konsentrasi dan dosis infusa daun yang digunakan belum optimal. Dosis infusa daun 5\% yang digunakan merupakan dosis awal yang diujicobakan untuk mengetahui efek hipoglikemik infusa daun tanaman makasar. Beberapa penelitian lainnya yang mengkaji efek hipoglikemik ekstrak air daun tanaman menggunakan dosis minimal 5\% dan 10\% (Njagi et al., 2015). Adapun dosis obat glibenclamid yang digunakan merupakan dosis tunggal yang terlalu rendah, sehingga tidak dapat menurunkan kadar gula darah puasa tikus mencapai kadar gula normal. 
Dosis tunggal yang seharusnya digunakan adalah $2 \times 0,25 \mathrm{mg} / \mathrm{kg} \mathrm{BB}$ sesuai dengan hasil konversi dari dosis manusia (5 mg/70 kg BB) (Medscape, 2017).

Induksi dengan aloksan menyebabkan kerusakan pada pankreas tikus. Aloksan bekerja mereduksi selsel $\beta$ pankreas dengan membentuk spesies reaktif oksigen seperti nitrat oksida (Njogu et al., 2016), sehingga pankreas tidak dapat mensintesis insulin dengan normal dan tikus menjadi hiperglikemik (Walvekar et al., 2016). Pemberian obat glibenclamid (golongan sulfonylurea) pada kontrol positif dapat meningkatkan sekresi insulin dari pankreas. Mekanisme kerja glibenclamid dalam menurunkan kadar gula darah kemungkinan melalui interaksinya dengan reseptor sulfonylurea pada sel $\beta$ atau mengganggu kanal potassium ATP-sensitive pada pada sel $\beta$ pankreas sehingga dapat meningkatkan sekresi insulin (Papich, 2016).

Mekanisme penurunan kadar gula darah puasa tikus hiperglikemik setelah pemberian ekstrak tanaman makasar belum diketahui dengan pasti. Noorshahida et al., (2009) menyatakan kemungkinan mekanisme ekstrak biji buah makasar dalam menurunkan kadar gula darah puasa yaitu merangsang sekresi insulin dan memperbaiki kerusakan sel $\beta$ pankreas setelah dirusak oleh aloksan. Penurunan kadar gula darah puasa tikus setelah pemberian infusa daun tanaman makasar memungkinkannya dapat memperbaiki kerusakan sel $\beta$ pankreas dan merangsang sintesis insulin.

Senyawa-senyawa yang dilaporkan bertanggung jawab pada efek hipoglikemik tikus diabetes dalam ekstrak biji buah makasar adalah brucein A dan D (Noorshahida et al., 2009), sedangkan pada bagian daun belum dilaporkan. Dengan demikian, senyawa aktif antidiabetes dalam ekstrak daun tanaman makasar masih memerlukan kajian lebih lanjut.

\section{K E S I M P U L A N}

Ekstrak infusa daun tanaman makasar dosis 5\% dapat menurunkan kadar gula darah puasa tikus yang diinduksi dengan aloksan meskipun hasilnya tidak signifikan.

\section{DAFTAR REFERENSI}

Ablat A, Mohamad J, Awang K, Shilpi JA, Arya A. 2014. Evaluation of Antidiabetic and Antioxidant Properties of Brucea javanica Seed. Hindawi Publishing Corporation, The Scientific World Journal, volume 2014, http://dx.doi.org/10.1155/2014/ 786130.

Chackrewarthy S, Tahbrew MI. 2014. Hypoglycaemic and Hypolipidaemic Effects of an Ethylacetate Fraction of Artocarpus heterophyllus Leaves. Chapter 12. http://dx.doi.org/ $10.5772 / 52538$

Chang CLT, Lin Y, Bartolome AP, Chen YC, Chiu SC, Yang WC. 2013. Review Article Herbal Therapies for Type 2 Diabetes Mellitus: Chemistry, Biology, and Potential Application of Selected Plants and Compounds. Evidence-Based Complementary and Alternative Medicine. Vol. 2013. Article ID 378657. Hindawi Publishing Corporation. 33 p.
Coman C, Rugina OD, Socaciu C. 2012. Plants and Natural Compounds with Antidiabetic Action. Notulae Botanicae Horti AgrobotaniciCluj-Napoca. 40(1):314-325, Print ISSN 0255965X; Electronic 1842-4309.

Eid HM, Haddad PS. 2014. Review Article: Mechanisms of Action of Indigenous Antidiabetic Plants from the Boreal Forest of Northeastern Canada. Journal of Advances in Endocrinology. 2014:1-11.

Issa IA, Bule MH. 2015. Hypoglycemic Effect of Aqueous and Methanolic Extract of Artemisia afra on Alloxan Induced Diabetic Swiss Albino Mice. Evidence-Based Complementary and Alternative Medicine. Volume 2015. Article ID 752486. http://dx.doi.org/10.1155/2015/752486. 5 p.

Hout S, Chea A, Bun S, Elias R, Gasquet M, Timon-David P, Balansard G, Azas N. 2006. Screening of selected indigenous plants of Cambodia for antiplasmodial activity. Journal of Ethnopharmacology. 107(1):12-18.

Medscape. 2017. Glyburide: Dosing and uses. https://reference. medscape.com.

Nasution R, Barus T, Nasution P, Saidi N. 2014. Isolation and Structure Elucidation of Steroid from Leaves of Artocarpus camansi (Kulu) as Antidiabetic. International Journal of PharmTech Research CODEN (USA). 6(4):1279-1285.

Njagi JM, Ngugi MP, Kibiti CM, Ngeranwa J, Njue W, Gathumbi P, Njagi E. 2015. Hypoglycemic effect of Helichrysum odoratissimum in alloxan induced diabetic mice. The Journal of Phytopharmacology (JPHYT0). 4(1):30-33.

Njogu SM, Arika WM, Nyamai DW, Ngugi MP, Machocho AK, Ngeranwa JJN, Njagi ENM. 2016. Hypoglycemic effect of aqueous and ethyl acetate leaf extract of Maytenus putterkloides in alloxan induced diabetic mice. Journal of Diabetes \& Metabolism. 7(6):685.

Noorshahida A, Wong TW, Choo CY. 2009. Hypoglicemic effect of quassionoids from Brucea javanica (L) Merr (Simaroubaceae) seeds. Journal of Ethnopharmacology. 124(3):586-591.

Okuyama E, Gao LH, Yamazaki M. 1990. Studies on pharmacologically active principles from Indonesia crude drugs. III. Toxic components from Brucea javanica (L) Merr. Yakugaku Zasshi. 110(11):834-838.

Osadebel PO, Odoh EU, Uzor PF. 2014. Review: The search for new hypoglycemic agents from plants. African Journal of Pharmacy Fand Pharmacology. 8(11):292-303.

Papich MG. 2016. Saunders Handbook of Veterinary Drugs (Fourth Edition). P. 359-360. http://doi.org/10.1016/B978-0-32324485-5-00283-7.

Prameswari OM, Widjanarko SB. 2014. Uji Efek Ekstrak Air Daun Pandan Wangi Terhadap Penurunan Kadar Glukosa Darah Dan Histopatologi Tikus Diabetes Mellitus. Jurnal Pangan dan Agroindustri. 2(2):16-27.

Sakaki T, Yoshimura S, Tsuyuki T, Takahasi T, Honda T, Nakanishi T. 1986. Structures of Yadanziosides K, M, N, and O, New Quassinoid Glycosides from Brucea javanica (L.) MERR. Bulletin of the Chemical Society of Japan. 59(11):3541-3546.

Walvekar MV, Potphode ND, Desai SS, Deshmukh VM. 2016. Histological Studies on Islets of Langerhans of Pancreas in Diabetic Mice after Curcumin Administration. International Journal of Pharmaceutical and Clinical Research. 8(9):13141318.

World Health Organization. 2000. Global Report On Diabetes. Available from: http://apps.who.int/iris/bitstream/10665/ 204871/1/9789241565257_eng.pdf 